\title{
Physiological responses of a small Antarctic diatom (Chaetoceros sp.) to simulated environmental constraints associated with sea-ice formation
}

\author{
Markus Gleitz, David N. Thomas
}

Alfred-Wegener-Institut für Polar- und Meeresforschung, Postfach 120161, W-2850 Bremerhaven, Germany

\begin{abstract}
The physiological responses of a small unicellular Chaetoceros species, isolated from the Weddell Sea, Antarctica, to changes in temperature, salinity and irradiance simulating those that occur during new-ice formation were investigated. The combination of increased salinity, increased quantum irradiance and decreased temperature significantly reduced growth and photosynthetic rates compared to the control, although cellular metabolism was not inhibited. The cells retained the capacity to photoacclimate, which was observed in the variations in cellular chlorophyll a concentrations and carbon allocation patterns. In terms of photosynthesis, a doubling of quantum irradiance apparently compensated for the adverse effects of increased salinity and lowered temperature. It is thus hypothesized that at least some species of the late season phytoplankton population survive incorporation into ice and continue to photosynthesize and grow under the extreme conditions encountered during sea-ice formation. This potentially prolonges the Antarctic vegetation period well into late austral autumn and winter, enhancing the total primary production available for higher trophic levels.
\end{abstract}

\section{INTRODUCTION}

A predominant feature of the Antarctic marine ecosystem is the formation and melting of about $16 \times$ $10^{6} \mathrm{~km}^{2}$ of sea ice during the course of the year (Zwally et al. 1983). Extensive sea ice formation commences in late summer and autumn in the open ocean by means of frazil ice production in the upper water column, giving rise to the so-called 'pancake ice cycle' (Lange et al. 1989). This process of new-ice formation has been shown to be of major importance for the establishment of the Antarctic sea ice cover (Weeks \& Ackley 1982, Lange et al. 1989). Frazil ice crystals produced in a turbulent environment effectively scavenge and concentrate planktonic organisms into a growing ice sheet, although the exact physical mechanisms of this process are still a matter of debate (Garrison et al. 1983, Garrison et al. 1989, Garrison 1991).

The incorporation of phytoplankton into a forming ice matrix is associated with profound changes in abiotic conditions, the most prominent being a confinement to a minute but dynamic pore system; an initial increase in light availability due to a stabilized ice layer at the sea surface followed by a gradual decrease as the ice thickens and the season progresses; and a decrease in temperature to values well below the freezing point of seawater (Palmisano \& Sullivan 1982, Eicken 1992, Weissenberger et al. 1992). As no salt ions are incorporated into the ice lattice in the process of sea-ice formation, all dissolved constituents are concentrated in the brine as a function of the ambient ice temperature (Weeks \& Ackley 1982, Maykut 1985). Thus, salinity as well as nutrient concentrations in the brine of newly formed sea ice may be significantly higher than in seawater.

The ecophysiological aspects of sea-ice breakup and the release of ice algae into the water column in spring have received considerable attention (Garrison et al. 1987, Gleitz \& Kirst 1991, Riebesell et al. 1991); however, there have been few attempts to study synergistic effects of changes related to new-ice formation. Bartsch (1989) and Aletsee \& Jahnke (1992) demonstrated that several sea ice diatoms are able to photosynthesize and grow at salinities of up to $145 \%$ at an equilibrium temperature of $-8^{\circ} \mathrm{C}$, even at very low irradiances. Lizotte \& Sullivan (1991) provided evidence for in situ 
activity of sea ice microalgae during austral autumn and winter. Contrary to these findings are observations by Dieckmann et al. (1991), who analyzed the nutrient status of young sea ice $(<2$ mo old). They concluded that despite the presence of a sea ice microbial community, only minor biological consumption of macronutrients may have taken place.

Sea ice microbial communities may develop in the course of new-ice formation provided that at least some phytoplankton species survive incorporation into ice. Seeding of sea ice from the water column after the initial establishment of an ice cover cannot be ruled out, even though lack of a significant phytoplankton biomass beneath young sea ice virtually excludes such a mechanism (Garrison et al. 1983, Bartsch 1989). If sea ice algal communities originate from phytoplankton scavenging, the ability of a microalga to acclimate to the prevailing physico-chemical conditions in newly formed sea ice will determine species composition and subsequent successional patterns.

In this study, the physiological responses of a small unicellular Chatoceros species isolated from the Weddell Sea, Antarctica, to variations in temperature, salinity and light representative of those associated with initial stages of new-ice formation were studied in a controlled laboratory experiment. Such small Chaetoceros spp. dominate many Antarctic phytoplankton and sea ice communities, and the isolate employed here is thus considered to be a representative diatom with which to study tolerance and acclimation poten- tial to environmental constraints associated with the formation of annual sea ice (Thomas et al. 1992).

\section{MATERIALS AND METHODS}

The experimental isolate was collected during the ANT IX/2 expedition of the RV 'Polarstern' (Bathmann et al. 1992). It was maintained in unialgal culture (nonaxenic) at $0{ }^{\circ} \mathrm{C}$ in double-filtered $(0.2 \mu \mathrm{m})$ synthetic seawater (Wimex ${ }^{(}$hw marinemix + bio elements; Wiegandt GmbH, Krefeld, Germany) enriched with nutrients in accordance with von Stosch \& Drebes (1964), except that only one-tenth of the concentrations of $\mathrm{Mn}, \mathrm{PO}_{4}, \mathrm{NO}_{3}$ and EDTA were added.

Batch cultures were grown at $0^{\circ} \mathrm{C}$ and a photon flux density of $50 \mu \mathrm{mol} \mathrm{m} \mathrm{m}^{-2} \mathrm{~s}^{-1}$ supplied by fluorescent tubes (Osram, Lumilux deLuxe-Daylight L36W/12). After the initial $(t=0)$ measurements, the culture was split into 3 separate 3 l cultures (A1, A2, A3), which were treated over an $8 \mathrm{~d}$ experimental period as shown by the scheme in Fig. 1. Salinity was increased in steps of $5 \%$ by adding $100 \mathrm{ml}$ of $200 \%$ filtered synthetic seawater solution enriched with nutrients to the same proportion as the normal seawater medium used. When the salinities of $\mathrm{A} 2$ and $\mathrm{A} 3$ were increased, $100 \mathrm{ml}$ of seawater media was also added to A1 so that volume changes were comparable among the 3 batch cultures. Temperature was decreased in A3 according to the experimental scheme shown in Fig. 1, and a

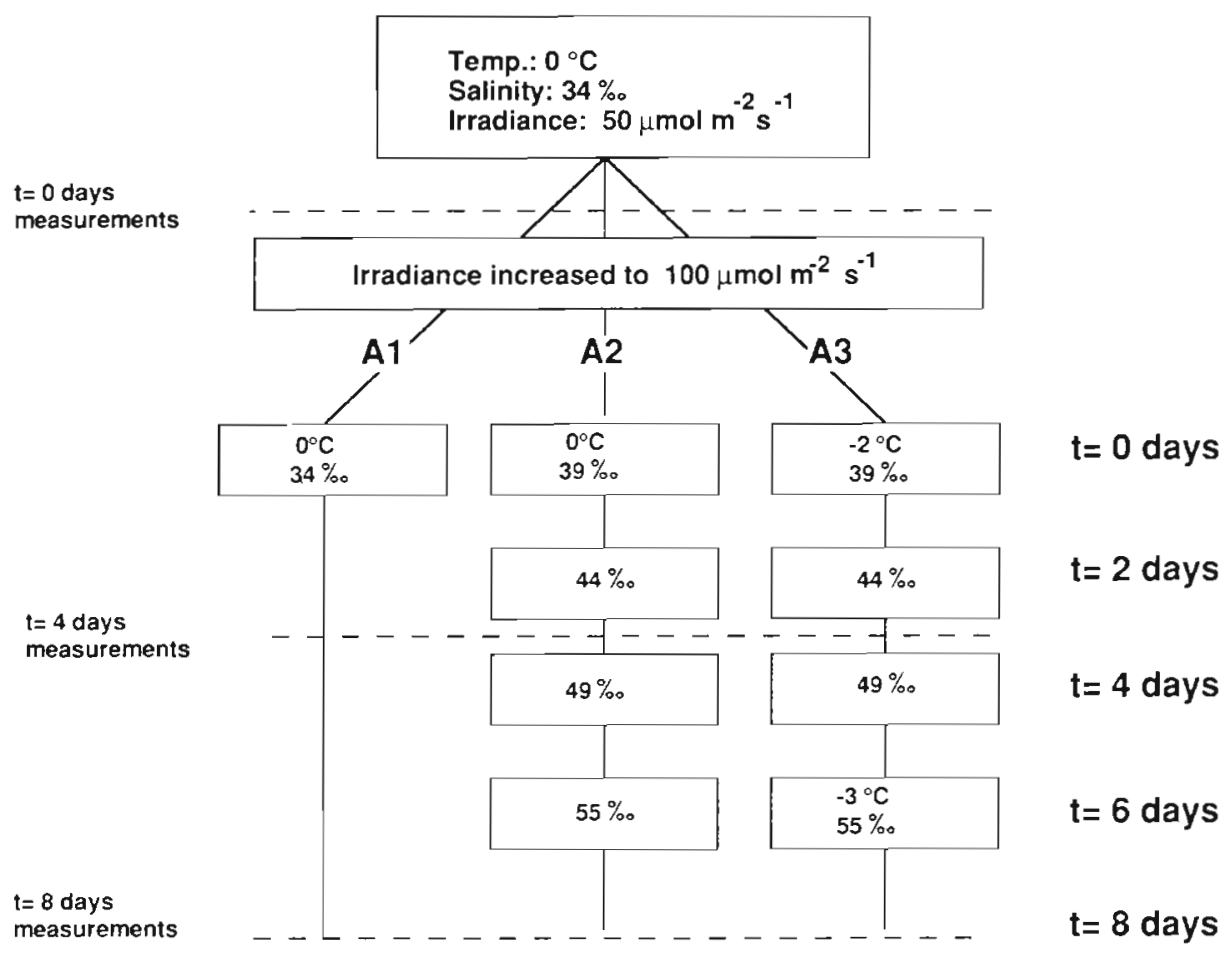

Fig. 1. Incubation and sampling scheme for simulated new-ice formation experiment. 
photoperiod of $16 \mathrm{~h}$ light: $8 \mathrm{~h}$ dark was employed throughout. At $t=0,4$ and $8 \mathrm{~d}$, samples were taken from the batch cultures for the following measurements and analyses.

Cell counts and chl a concentrations. Three replicate samples $(100 \mathrm{ml})$ were filtered onto glass fibre filters (Whatmann GF/C). Ch] a was extracted overnight in $90 \%$ acetone at $4{ }^{\circ} \mathrm{C}$ in the dark, and subsequently determined fluorometrically (Parsons et al. 1984). Cell numbers were estimated in $20 \mathrm{ml}$ subsamples preserved with formalin (final concentration: $0.1 \%$ ). Ten $\mathrm{ml}$ were placed in a sedimentation chamber, left overnight and counted according to Utermöhl (1958). Chl a measurements and cell counts were corrected for dilution due to brine or seawater additions.

Photosynthetic carbon assimilation. Triplicate bottles $(50 \mathrm{ml})$ were incubated for $4 \mathrm{~h}$ with $3.7 \mathrm{kBq} \mathrm{ml}^{-1}$ of $\mathrm{NaH}^{14} \mathrm{CO}_{3}$ (Amersham Buchler $\mathrm{GmbH}$ ) at the irradiance and temperature from which the samples had been taken. At the same time triplicate bottles were incubated in the dark in order to measure the extent of dark carbon assimilation. This value was subtracted from the light uptake measurement. Incubations were terminated by filtering through cellulose nitrate membrane filters $(0.2 \mu \mathrm{m}$; Sartorius $\mathrm{GmbH})$, which were subsequently dried at $60^{\circ} \mathrm{C}$, briefly exposed to fuming $\mathrm{HCl}$ and then dissolved in $5 \mathrm{ml}$ scintillation cocktail (Quickzint $361^{\circledR}$; Zinsser GmbH). The total concentration of inorganic carbon species was calculated from alkalinity determinations using an endpoint titration method (Almgren et al. 1983). The specific activity of radiolabel was determined by removing $100 \mu \mathrm{l}$ of media immediately after addition of radiolabel, adding it to $2 \mathrm{ml}$ of $\mathrm{NaOH}(0.05 \mathrm{~N})$, and subsequently measuring activity after addition of $3 \mathrm{ml}$ scintillation cocktail (Quickzint $1^{\oplus}$; Zinsser $\mathrm{GmbH}$ ). Throughout the study, a Packard Tri-Carb ${ }^{\circledR} 460 \mathrm{C}$ liquid scintillation counter was used, and quench correction was performed automatically using an external standard.

End products of photosynthesis. A second triplicate series of bottles $(50 \mathrm{ml}$ ) was incubated at the same time with $\mathrm{NaH}^{14} \mathrm{CO}_{3}$, although this was added at a specific activity of $7.4 \mathrm{kBq} \mathrm{m} l^{-1}$. This series was incubated for $10 \mathrm{~h}$ before the samples were filtered onto glass fibre filters (Whatmann GF/C), which were rinsed with unlabeled cold media and stored at $-30^{\circ} \mathrm{C}$ until further analysis. The end products of photosynthesis in cells retained on the filters were separated and quantified using a differential extraction scheme based on that described by Li et al. (1980). Thawed filters were dried at $60^{\circ} \mathrm{C}$, and subsequently extracted in chloroform: methanol: water $(1: 2: 0.8 \mathrm{v} / \mathrm{v} / \mathrm{v})$ at $4{ }^{\circ} \mathrm{C}$ for $10 \mathrm{~min}$. After gentle centrifugation phase separation produced a chloroform-soluble fraction and a methanol/watersoluble fraction. Filters were further extracted in boiling $5 \%$ trichloroacetic acid (TCA) for 30 min, rinsed with cold TCA, and the supernatant stored. The TCA-insoluble residue remaining on the filters was retained, and total volumes of all liquid fractions recorded. This procedure is assumed to yield 4 major fractions: lipids, low-molecular-weight metabolites, protein and polysaccharide. The uptake of radiolabeled carbon into the fractions was measured by liquid scintillation counting.

Statistical determinations. Standard errors for cellular chlorophyll concentrations (see Fig. 2b) and photosynthetic rates (see Fig. 3) were calculated according to Gauss' law of error propagation (Kreyszig 1982).

\section{RESULTS}

\section{Cell counts and chl a concentrations}

Variations in cell numbers and pigment concentrations are depicted in Fig. 2. In all 3 series, growth was sustained, even though there were clear differences with respect to increases in cell density (Fig. 2a). At $0{ }^{\circ} \mathrm{C}$, an increase in salinity from 34 to $44 \%$ (A.2) had
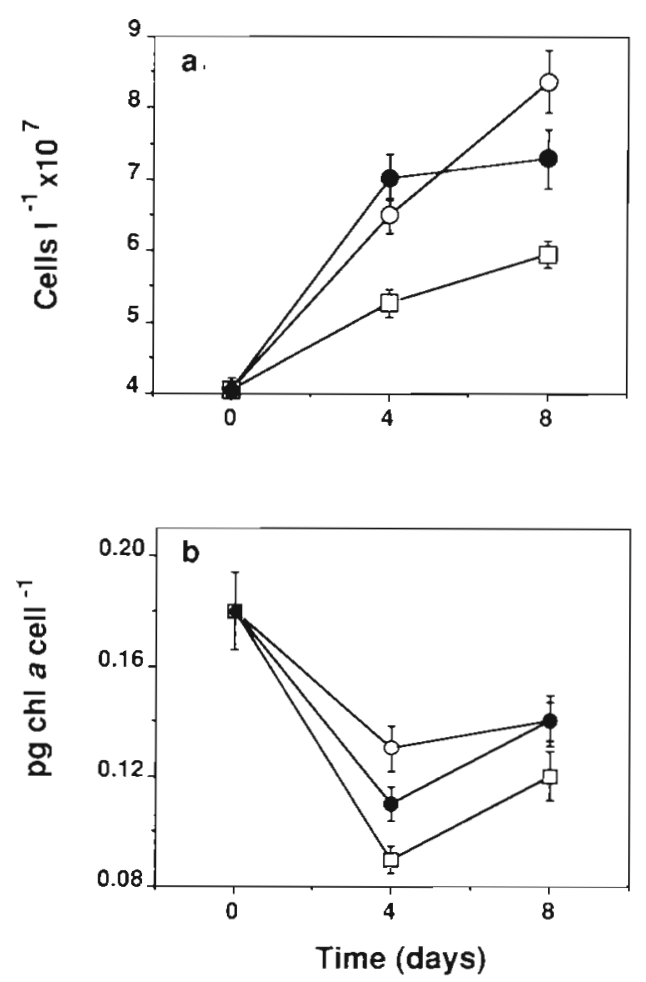

Fig. 2. Chaetoceros sp. (a) Cell density and (b) cellular chl a concentration after 0,4 and $8 \mathrm{~d}$ in 3 incubation series with Chaetoceros sp. Values were corrected for seawater (A1) or brine (A2, A3) dilutions. For incubation conditions see Fig. 1. (0) A1; (•) A2; ( $)$ ) A3. Bars indicate the standard error 

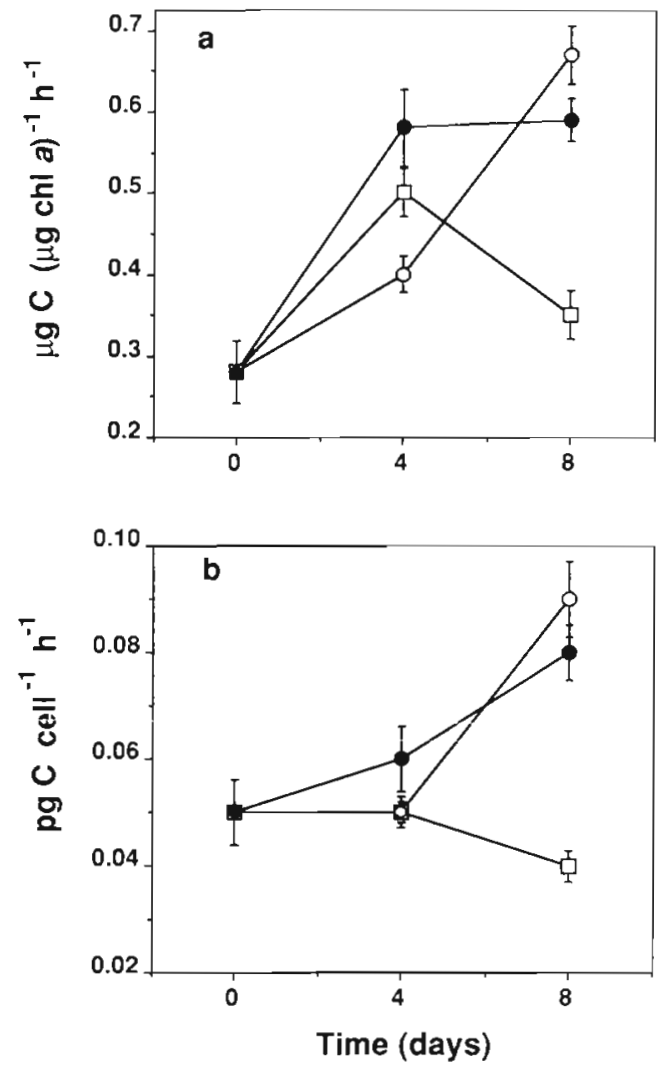

Fig. 3. Chaetoceros sp. Photosynthetic rates after 0,4 and $8 \mathrm{~d}$ in 3 incubation series. For incubation conditions see Fig. 1. (a) Photosynthetic rates normalized to chl a concentration, and (b) photosynthetic rates normalized to cell density. Symbols as in Fig. 2

no significant effect on growth rate compared to the control (A1), whereas a concomitant decrease in temperature from 0 to $-2{ }^{\circ} \mathrm{C}$ (A3) significantly reduced growth. In A3, cell numbers continued to increase after $t=4 \mathrm{~d}$ despite further salinity and temperature variations. On the other hand, an increase in salinity to $55 \%$ at a constant temperature of $0^{\circ} \mathrm{C}$ inhibited increases in cell number after $t=4 \mathrm{~d}$ (A2).

Microscopic examination of the samples showed no significant change in mean cell size in any incubation series (valve diameter 5 to $10 \mu \mathrm{m}$ ). Variations in chl a per cell, however, were observed in all 3 incubation series (Fig. 2b). The increase in photon flux density from 50 to $100 \mu \mathrm{mol} \mathrm{m} \mathrm{m}^{-2} \mathrm{~s}^{-1}$ in A1 led to a ca $30 \%$ decrease in chl a per cell after an $8 \mathrm{~d}$ period. The initial salinity and temperature manipulations $(t=4 \mathrm{~d}, \mathrm{~A} 2$ and A3) clearly enhanced this effect. Pigment concentration per cell, however, increased again to the control value in $A 2$ after $8 \mathrm{~d}$ even when salinity was increased to $55 \%$. Similarly, chI a per cell also increased in A3, even though pigment content in this case was still ca $15 \%$ lower after $8 \mathrm{~d}$ when compared to the control.

\section{Photosynthetic carbon assimilation}

The photosynthetic performance of Chaetoceros sp. is depicted in Fig. 3. Normalized to chl a, photosynthetic rates were significantly higher at $100 \mu \mathrm{mol} \mathrm{m} \mathrm{m}^{-2} \mathrm{~s}^{-1}(t=$ $4 \mathrm{~d}$ ) in all incubation series as compared with the $t=0$ measurement at $50 \mu \mathrm{mol} \mathrm{m} \mathrm{m}^{-2} \mathrm{~s}^{-1}$ (Fig. 3a). At the same time, rates after $4 \mathrm{~d}$ were higher in $\mathrm{A} 2$ and $\mathrm{A} 3$ when compared to the control. The photosynthetic capacity measured after $8 \mathrm{~d}$ in the control almost doubled, even though irradiance was kept constant at $100 \mu \mathrm{mol} \mathrm{m}^{-2} \mathrm{~s}^{-1}$. A further increase in salinity prevented a similar enhancement of photosynthetic rate in A2. A concomitant decrease in temperature (A3), on the other hand, resulted in a ca $30 \%$ decrease in chl a specific photosynthetic rate. Normalized to cell numbers (Fig. 3b), photosynthetic rate in the control remained constant over $4 \mathrm{~d}$, then almost doubled at $t=8 \mathrm{~d}$. A similar trend was observed for the A2 incubation, even though photosynthetic rate was slightly higher at $t=4 \mathrm{~d}$ and slightly lower at $t=8 \mathrm{~d}$. When temperature and salinity were both manipulated (A3), photosynthetic performance on a per cell basis was equal to the control value after $4 \mathrm{~d}$, but then decreased slightly at $t=8 \mathrm{~d}$.

\section{End products of photosynthesis}

Only slight differences among the 3 experimental series were observed with respect to relative ${ }^{14} \mathrm{C}$ incorporation into low-molecular-weight metabolites (LMWM), lipid (LIP), protein (PROT) and polysaccharide (POLY) over the $8 \mathrm{~d}$ incubation period (Fig. 4). The most prominent feature in all 3 cases was a substantial increase in the fraction of LMWM associated with an increase in irradiance from 50 to $100 \mu \mathrm{mol} \mathrm{m} \mathrm{m}^{-2} \mathrm{~s}^{-1}$. In contrast to photosynthetic performance, allocation patterns in the control sample remained constant after $4 \mathrm{~d}$. In A2 and A3, relative incorporation of radiolabel into LMWM continued to increase. This was counterbalanced by a slight decrease in ${ }^{14} \mathrm{C}$ allocation into polymeric compounds (POLY, LIP and PROT).

\section{DISCUSSION}

\section{Cell counts and chl a concentrations}

The small unicellular Chaetoceros sp. employed in this study continued to divide when subjected to an increase in salinity from 34 to $55 \%$ at a corresponding equilibrium temperature range of 0 to $-3^{\circ} \mathrm{C}$ and an increase in irradiance from 50 to $100 \mu \mathrm{mol} \mathrm{m} \mathrm{m}^{-2} \mathrm{~s}^{-1}$. These are realistic changes comparable to those observed during initial stages of new-ice formation in the 


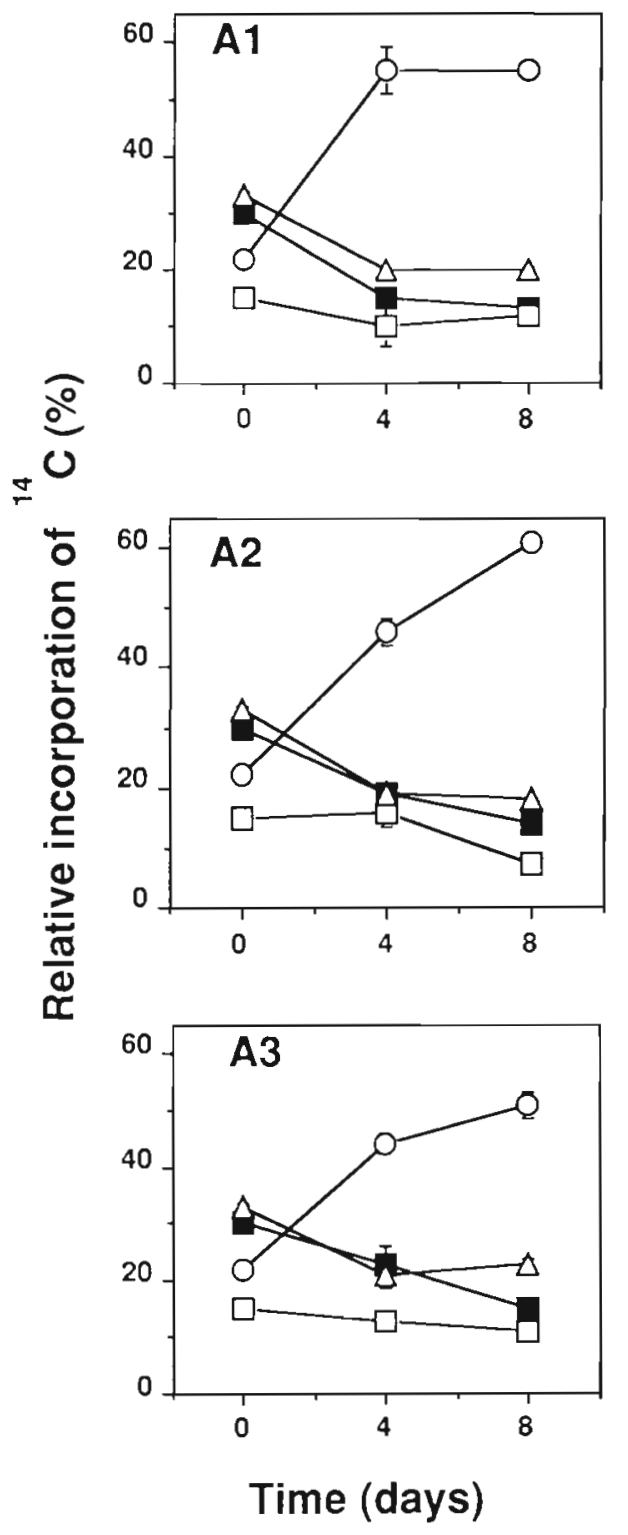

Fig. 4. Chaetoceros sp. Relative allocation of photoassimilated carbon into the metabolic pools of low-molecular-weight metabolites (LMWM), lipids (LIP), protein (PROT) and polysaccharides (POLY) in the 3 incubation series $A 1, A 2, A 3$ (see Fig. 1). Total uptake was taken as the $100 \%$ value. Bars indicate the standard error of triplicate determinations. (O) LMWM; ( 1 ) LIP; ( $\square$ ) POLY; ( $\triangle$ ) PROT

southeastern Weddell Sea, in late summer and autumn (Gleitz 1992, author's unpubl. results). Consequently, this species may survive incorporation into ice, even though growth is substantially reduced under conditions simulating new-ice formation. A similar response in growth rate to environmental constraints brought about by salinity and temperature variation was observed for several Antarctic sea ice diatoms by Bartsch (1989). Aletsee \& Jahnke (1992) subjected cultures of Thalassiosira antarctica and Nitzschia frigida to a decrease in temperature from 0 to $-4{ }^{\circ} \mathrm{C}$ and report that $60 \%$ of the cells survived in the remaining liquid. Both species grew exponentially up to a salinity of $109 \%$ and a temperature of $-6^{\circ} \mathrm{C}$ after adaptation to the respective test conditions. In the present study, the increase in cell number after the second manipulation $(t=4 \mathrm{~d})$ in A.3 was less restrained than in A2 (Fig. 2a), which may indicate that tolerance to high salinities increases with lower temperatures. Observations made by Aletsee \& Jahnke (1992) support this suggestion.

Microscopical examination of the Chaetoceros $\mathrm{sp}$. culture over the course of the experiment revealed no significant variation of the mean cell size. Therefore, changes in chl a per cell as recorded in A.1 are in agreement with generally accepted photoacclimation theory, where a decrease in pigment concentrations in microalgal cells as a response to higher quantum irradiances is brought about by decreases in the number or size of photosystems (Richardson et al. 1983). Similar observations were made by Michel et al. (1988) for natural populations of sea ice microalgae and by Thomas et al. (1992) for the Chaetoceros clone employed in this study. Aletsee \& Jahnke (1992) recorded a reduction in chl a concentration per cell with increasing irradiances at temperatures below the freezing point of seawater for Thalassiosira antarctica and Nitzschia frigida. It is thus concluded that the decrease in pigment content in $\mathrm{A} 3$ demonstrates this Chaetoceros sp. to be capable of sustaining its photoacclimation potential when exposed to physico-chemical conditions simulating new-ice formation on a time scale of days. The lowest cellular chlorophyll concentrations were recorded when temperature and salinity acted synergistically (A3). It is hypothesized that in order to meet carbon and energy requirements necessary for osmoacclimation processes (i.e. synthesis of osmolytes, fueling of membrane-bound ion pumps; see Kirst 1990), the rearrangement of pigment concentrations may be disturbed. Thus, readjustment of cellular chl a content may be incomplete after $8 \mathrm{~d}$ when compared to the supposedly optimal concentration (as observed in $\mathrm{A}$.1).

\section{Photosynthetic carbon assimilation}

An increase in chlorophyll-specific photosynthetic rate induced by a shift from a low- to a high-light environment is a photoacclimation strategy frequently observed in microalgal cells (Richardson et al. 1983). A similar response was also recorded for natural sea ice algal communities as well as for the Chaetoceros clone employed in the present study (Palmisano et al. 1985, 
1987. Thomas et al. 1992). Variations in photosynthetic capacity on a chl a as well as on a per cell basis (A1; Fig. 3) reveal that photoacclimation in this Chaetoceros clone at $0^{\circ} \mathrm{C}$ was not fully achieved over the experimental period. This is documented by the continuous increase in chl a-specific assimilation rate after $4 \mathrm{~d}$, even though quantum irradiance remained constant. At the same time, only after $8 \mathrm{~d}$ was the alga able to use a higher quantum flux for a higher carbon assimilation rate on a per cell basis. Obviously, due to the substantial variations in cellular chl a concentration, normalizing photosynthetic rate to chl a concentration may be misleading when evaluating carbon assimilation efficiency under transient, sub-optimal conditions.

The results obtained in this study suggest that in terms of carbon assimilation per cell under conditions simulating initial stages of ice formation (A3), this Chaetoceros $\mathrm{sp}$. is unable to make use of higher irradiances which may be prevalent when phytoplankton cells are transferred from an oceanic, turbulent environment with deep mixing to a stable ice matrix at the sea surface. The cells continue to photosynthesize, however, at a rate comparable to that observed at the start of the experiment $\left(34 \%, 0^{\circ} \mathrm{C}\right.$ and $50 \mu \mathrm{mol}$ $\mathrm{m}^{-2} \mathrm{~s}^{-1}$ ), and the adverse effects of temperature and salinity are apparently balanced by the increase in irradiance.

\section{End products of photosynthesis}

Changes in the patterns of photosynthetic carbon assimilation in natural sea ice algal communities as well as in selected ice algal species have in numerous studies been interpreted in terms of environmental constraints such as nutrient limitation, sub-optimal temperatures or light and salinity variations profoundly influencing the physiological state of the algae (McConville et al. 1985, Palmisano \& Sullivan 1985, Smith et al. 1987, Palmisano et al. 1988, Nichols et al. 1989, Tillmann et al. 1989, Gleitz \& Kirst 1991, Thomas \& Gleitz unpubl.). Increased carbon allocation into the fraction of LMWM as a response to higher incubation irradiances has been observed by Rivkin \& Voytek (1987) in a phytoplankton sample collected at the ice edge in McMurdo Sound, Antarctica. Smith et al. (1987), on the other hand, recorded a light-insensitive allocation into LMWM of about $40 \%$ in Arctic ice algae. A decrease in relative allocation into LMWM with increased quantum irradiance was observed for an interior ice algal community from the Weddell Sea, by Gleitz \& Kirst (1991). The cellular pool of LMWM comprises a wide variety of different compounds with equally diverse functions. For polar phytoplankton and ice algae, it is generally agreed that changes in
LMWM may be associated with processes involving osmoregulation, cryoprotection or accumulation of storage material (Rivkin \& Voytek 1987, Smith et al. 1987. Kirst 1990). Obviously, in the present study, the increase in relative allocation into the LMWM indicates that the effect of increasing quantum irradiance outweighed the influence of salinity and temperature changes, Due to the seawater additions, nutrient depletion presumably did not influence the observed carbon allocation patterns. Thomas \& Gleitz (unpubl.) suggest that carbon allocation in sea ice microalgae might be determined by growth rate and carbon turnover. As there was no initial increase in photosynthetic rate (on a per cell basis) associated with the variation in quantum irradiance (Fig. 3), the initial increase in LMWM after $4 \mathrm{~d}$ cannot be readily explained by changes in assimilation rates. Profound changes as a response to changes in light environment, however, were observed in all 3 incubation series for the cellular chl a content, and it may be hypothesized that the changes in carbon allocation within the LMWM observed at $t=4 \mathrm{~d}$ may be associated with pigment biosynthetic pathways, especially as ${ }^{14} \mathrm{C}$ incorporation into the lipid fraction, into which chl a is extracted, decreased substantially. The continuing increase in LMWM after $t=4 \mathrm{~d}$ in A2 and A3 may, on the other hand, have been influenced by the increase in salinity. In an experiment with a natural ice algal community, carbon allocation into LMWM increased proportionally with the salinity of the incubation medium. This was tentatively interpreted as an indication of enhanced osmolyte (i.e. proline) biosynthesis (author's unpubl. results). More detailed investigations, however, are clearly required to confidently resolve the carbon allocation patterns observed in this investigation.

\section{CONCLUSIONS}

As sea ice forms, a new and unique habitat for plankton organisms is created. The physiological responses observed in a small unicellular Chaetoceros sp. suggest that at least some species of the late season phytoplankton population in the Antarctic survive incorporation into ice and continue to photosynthesize and grow under conditions prevailing in newly formed sea jce. This may have important implications for the structure and dynamics of the Southern Ocean ecosystem. Physical accumulation processes concentrate phytoplankton cells in the newly formed ice sheet at the sea surface, which prevents these cells from being mixed out of the euphotic zone due to increased wind stress and thermohaline convection. We hypothesize that light availability for photosynthesis is initially enhanced until ice thickness, snow accumulation and 
sun angle severely restrict primary production for time scales of weeks to months. Up to that time, results presented here and other collaborating data suggest that despite drastic changes in the abiotic environment, some microalgae remain metabolically active and growth may contribute significantly to the high algal standing stocks frequently observed in young sea ice. Thus, late season primary production may be profoundly enhanced and the growth period of the phytoplankton significantly prolonged due to the formation of a stabilized ice cover on the sea surface.

Acknowledgements. We are grateful to Marcus Baumann for making his culture material available to us. We thank Sönnke Grossmann for helpful discussions during the preparation of the manuscript. This is publication no. 587 of the AlfredWegener-Institut für Polar- und Meeresforschung.

\section{LITERATURE CITED}

Aletsee, L., Jahnke, J. (1992). Growth and productivity of the psychrophilic marine diatoms Thalassiosira antarctica Comber and Nitzschia frigida Grunow in batch cultures at temperatures below the freezing point of sea water. Polar Biol. 11: 643-647

Almgren, T., Dyrssen, D., Fonselius, S. (1983). Determination of alkalinity and total carbonate. In: Grasshoff, K., Ehrhardt, M., Kremling, K. (eds.) Methods of seawater analysis, 2nd edn. Verlag Chemie, Weinheim, p. 99-123

Bartsch, A. (1989). Die Eisalgenflora des Weddellmeeres (Antarktis): Artenzusammensetzung und Biomasse sowie Ökophysiologie ausgewählter Arten. Ber. Polarforsch. 63

Bathmann, U., Schulz-Baldes, M., Fahrbach, E., Smetacek, V., Hubberten, H.-W. (eds.) (1992). Die Expeditionen ANTARKTIS $[X / 1-4$ des Forschungsschiffes 'Polarstern' 1990/91. Ber. Polarforsch. 100

Dieckmann, G. S., Lange, M. A., Ackley, S. F., Jennings, J. C. Jr (1991). The nutrient status in sea ice of the Weddell Sea during winter: effects of sea ice texture and algae. Polar Biol. 11: 449-456

Eicken, H. (1992). The role of sea ice in structuring Antarctic ecosystems. Polar Biol. 12: 3-13

Garrison, D. L. (1991). Antarctic sea ice biota. Am. Zool. 31: $17-33$

Garrison, D. L., Ackley, S. F., Buck, K. R. (1983). A physical mechanism for establishing algal populations in frazil ice. Nature 306: 363-365

Garrison, D. L., Buck, K. R., Fryxell, G. A. (1987). Algal assemblages in Antarctic pack ice and in ice-edge plankton. J. Phycol. 23: 564-572

Garrison, D. L., Close, A. R., Reimnitz, E. (1989). Algae concentrated by frazil ice: evidence from laboratory experiments and field measurements. Antarct. Sci. 1(4): $313-316$

Gleitz, M. (1992). Sea ice ecology: photosynthetic capacity and carbon metabolism of different ice algal communities. In: Bathmann, U., Schulz-Baldes, M., Fahrbach, E., Smetacek, V., Hubberten, H.-W. (eds.) Die Expeditionen ANTARKTIS IX/1-4 des Forschungsschiffes 'Polarstern' 1990/91. Ber. Polarforsch. 100: 146-150

Gleitz, M., Kirst, G. O. (1991). Photosynthesis-irradiance relationships and carbon metabolism of different ice algal assemblages collected from Weddell Sea pack ice during austral spring (EPOS 1). Polar Biol. 11: 385-392

Kirst, G. O. (1990). Salinity tolerance in eukaryotic marine algae. A. Rev. Plant Physiol. Plant Mol. Biol. 41: 21-53

Kreyszig, E. (1982). Statistische Methoden und ihre Anwendungen. Vandenhoeck und Ruprecht, Göttingen

Lange, M. A., Ackley, S. F., Wadhams, P., Dieckmann, G. S., Eicken, H. (1989). Development of sea ice in the Weddell Sea. Ann. Glaciol. 12: 92-96

Li, W. K. W., Glover, H. E., Morris, I. (1980). Physiology of carbon assimilation by Oscillatoria thiebautii in the Caribbean Sea. Limnol. Oceanogr. 25: 447-456

Lizotte, M. P., Sullivan, C. W. (1991). Photosynthesis-irradiance relationships in microalgae associated with Antarctic pack ice: evidence for in situ activity. Mar. Ecol. Prog. Ser 71. $175-184$

Maykut, G. A. (1985). The ice environment. In: Horner, R. (ed.) Sea ice biota. CRC Press, Boca Raton, Florida, p. 21-82

McConville, M. J., Mitchell, C., Wetherbee, R. (1985). Patterns of carbon assimilation in a microalgal community from annual sea ice, East Antartica. Polar Biol. 4: 135-141

Michel, C., Legendre, L., Demers, S., Therriault, J.-C. (1988). Photoadaptation of sea-ice microalgae in springtime: photosynthesis and carboxylating enzymes. Mar. Ecol. Prog. Ser. 50: 177-185

Nichols, P. D., Palmisano, A. C., Rayner, M. S., Smith, G. A., White, D. C. (1989). Changes in the lipid composition of Antarctic sea-ice diatom communities during a spring bloom: an indication of community physiological status. Antarct. Sci. 1: 133-140

Palmisano, A. C., Beeler Soo Hoo, J., Sullivan, C. W. (1985). Photosynthesis-irradiance relationships in sea ice microalgae from McMurdo Sound, Antarctica. J. Phycol. 21. $341-346$

Palmisano, A. C., Beeler Soo Hoo, J., Sullivan, C. W. (1987). Effects of four environmental variables on photosynthesisirradiance relationships in Antarctic sea-ice microalgae. Mar. Biol 94: 299-306

Palmisano, A. C., Lizotte, M. P., Smith, G. A., Nichols, P. D., White, D. C., Sullivan, C. W. (1988). Changes in photosynthetic carbon assimilation in Antarctic sea-ice diatoms during spring bloom: variations in synthesis of lipid classes. J. exp. mar. Biol. Ecol. 116: 1-13

Palmisano, A. C., Sullivan, C. W. (1982). Physiology of sea ice diatoms. I. Response of three polar diatoms to a simulated summer-winter transition. J. Phycol. 18: 489-498

Palmisano, A. C., Sullivan, C. W. (1985). Pathways of photosynthetic carbon assimilation in sea-ice microalgae from McMurdo Sound, Antarctica. Limnol. Oceanogr. 30: $674-678$

Parsons, T R., Maita, Y., Lalli, C. M. (1984). A manual of chemical and biological methods for seawater analysis. Pergamon Press, New York

Richardson, K., Beardall, J., Raven, J. A. (1983). Adaptation of unicellular algae to irradiance: an analysis of strategies. New Phytol. 93: 157-191

Riebesell, U., Schloss, I., Smetacek, V. (1991). Aggregation of algae released from melting sea ice: implications for seeding and sedimentation. Polar Biol. 11: 239-248

Rivkin, R. B., Voytek, M. A. (1987). Photoadaptations of photosynthesis and carbon metabolism by phytoplankton from McMurdo Sound, Antarctica. 1. Species-specific and community responses to reduced irradiances. Limnol. Oceanogr. 32: 249-259

Smith, R. E. H., Clement, P., Cota, G. F., Li, W. K. W. (1987). Intracellular photosynthate allocation and the control of Arctic marine ice algal production. J. Phycol. 23. 124-132 
Thomas, D. N., Baumann, M. E. M., Gleitz, M. (1992). Efficiency of carbon assimilation and photoacclimation in a small unicellular Chaetoceros species from the Weddell Sea (Antarctica): influence of temperature and irradiance. J. exp. mar. Biol. Ecol. 157: 195-209

Tillmann, U., Baumann, M. E. M., Aletsee, L. (1989). Distribution of carbon among photosynthetic end products in the bloom-forming Arctic diatom Thalassiosira antarctica Comber. Polar Biol. 10: 231-238

Utermöhl, H. (1958). Zur Vervollkommnung der quantitativen Phytoplankton-Methodik. Int. Ver. theor. angew. Limnol. Mitt. 9: 1-38

von Stosch, H. A., Drebes, G. (1964). Entwicklungsgeschichtliche Untersuchungen an zentrischen Diatomeen. IV. Die

This article was submitted to the editor
Planktondiatomee Stephanopyxis turris, ihre Behandlung und Entwicklungsgeschichte. Helgoländer wiss. Meeresunters. 11: 209-257

Weeks, W. F, Ackley, S. F. (1982). The growth, structure and properties of sea ice. CRREL Monograph 82-1, Cold Reg. Res. Eng. Lab., Hanover, New Hampshire

Weissenberger, J., Dieckmann, G., Gradinger, R., Spindler M. (1992). Sea ice: a cast technique to examine and analyze brine pockets and channel structure. Limnol. Oceanogr. 37(1): 179-183

Zwally, H. J., Parkinson, C. L., Comiso, J. C. (1983). Variability of Antarctic sea ice and changes in carbon dioxide. Science 220: 1005-1012

Manuscript first received: July 31, 1992

Revised version accepted: October 8, 1992 